\title{
Effect of NPK fertilization on the chemical properties and bioactive compounds of the cabezona pineapple fruit
}

\author{
Pérez-Romero Juventino ${ }^{1}$, Salgado-Garcia Sergio ${ }^{* 1}$, Lagunes-Espinoza L. del Carmen ${ }^{1}$, \\ Córdova-Sánchez Samuel ${ }^{2}$, Ortiz-García C. Fredy ${ }^{* 1}$
}

1 Colegio de Postgraduados-Campus Tabasco, Producción Agroalimentaria en el Trópico. Km. 3.5 Periférico Carlos A. Molina S/N. H. Cárdenas, Tabasco. CP 86500. México.

2 Universidad Popular de la Chontalpa. División Académica de Ciencias Básicas e Ingenierías. GA-QVyDS. Carretera Cárdenas - Huimanguillo, Km. 2.0 Cárdenas, Tabasco, México. CP. 86500.

* Correspondence: salgados@colpos.mx; cfortiz@colpos.mx

\begin{abstract}
Gitation: Pérez-Romero J., SalgadoGarcia S., Lagunes-Espinoza L. del C. Córdova-Sánchez S. \& Ortiz-García C. F. (2021). Effect of NPK fertilization on the chemical properties and bioactive compounds of the cabezona pineapple fruit. Agro Productividad. https://doi. org/10.32854/agrop.v14il0.1803
\end{abstract}

Editor in Chief: Dr. Jorge Cadena Iñiguez

Received: March 28, 2021. Accepted: August 15, 2021. Published on-line: November 10, 2021 .

This work is licensed under a Creative Commons Attribution-NonCommercial 4.0 International license.

\section{ABSTRACT}

Objective: To evaluate the effect of NPK fertilization on the chemical properties and bioactive compounds of the cabezona pineapple fruit.

Design/methodology/approach: 15 NPK fertilization treatments were evaluated and carried out in the field in a random complete block design with four repetitions per treatment. At the end of the crop cycle, we determined the $\mathrm{pH},{ }^{\circ} \mathrm{Brix}$ and citric acid $\%$ of the fruits that were harvested, following the methodology established in NMX-FF-028 and 011 . The $\mathrm{pH}$ of the juice was measured directly using a potentiometer. Ascorbic acid was measured with a SIGMA-ALDRICH ${ }^{\circledR}$ kit, the total polyphenol contents were determined following the methodology of De la Cruz-Ricardez et al. (2020), while total flavonoid contents were measured following a modified version of the methodology proposed by Hossain et al. (2011).

Results: The mean values for ${ }^{\circ} \mathrm{Brix}$, citric acid \%, and $\mathrm{pH}$ were $7.3,7.1$ and 3.4 respectively, without significant differences between treatments. A highly significant difference in the concentration of ascorbic acid was observed between treatments; treatment three had the highest concentration $\left(19.4 \mathrm{mg} 100 \mathrm{~g}^{-1} \mathrm{FF}\right)$. There were no significant differences between the fertilization treatments and the control, regarding total polyphenol content (41.34 mg $\left.100 \mathrm{~g}^{-1} \mathrm{FF}\right)$ and flavonoids (1.6 mg $\left.100 \mathrm{~g}^{-1} \mathrm{FF}\right)$ concentrations.

Study limitations/implications: The ripening degree of the pineapple fruit directly influences the chemical properties and the concentration of bioactive compounds.

Findings/conclusions: NPK fertilization had no effect on ${ }^{\circ}$ Brix and $\mathrm{pH}$. The citric acid percentage and the total polyphenol content increased as the doses of $\mathrm{P}_{2} \mathrm{O}_{5}$ increased. The ascorbic acid concentration and total flavonoid content are not affected by the NPK fertilization dose.

\section{Keywords: Cabezona pineapple, NPK fertilization, chemical properties, bioactive compounds.}

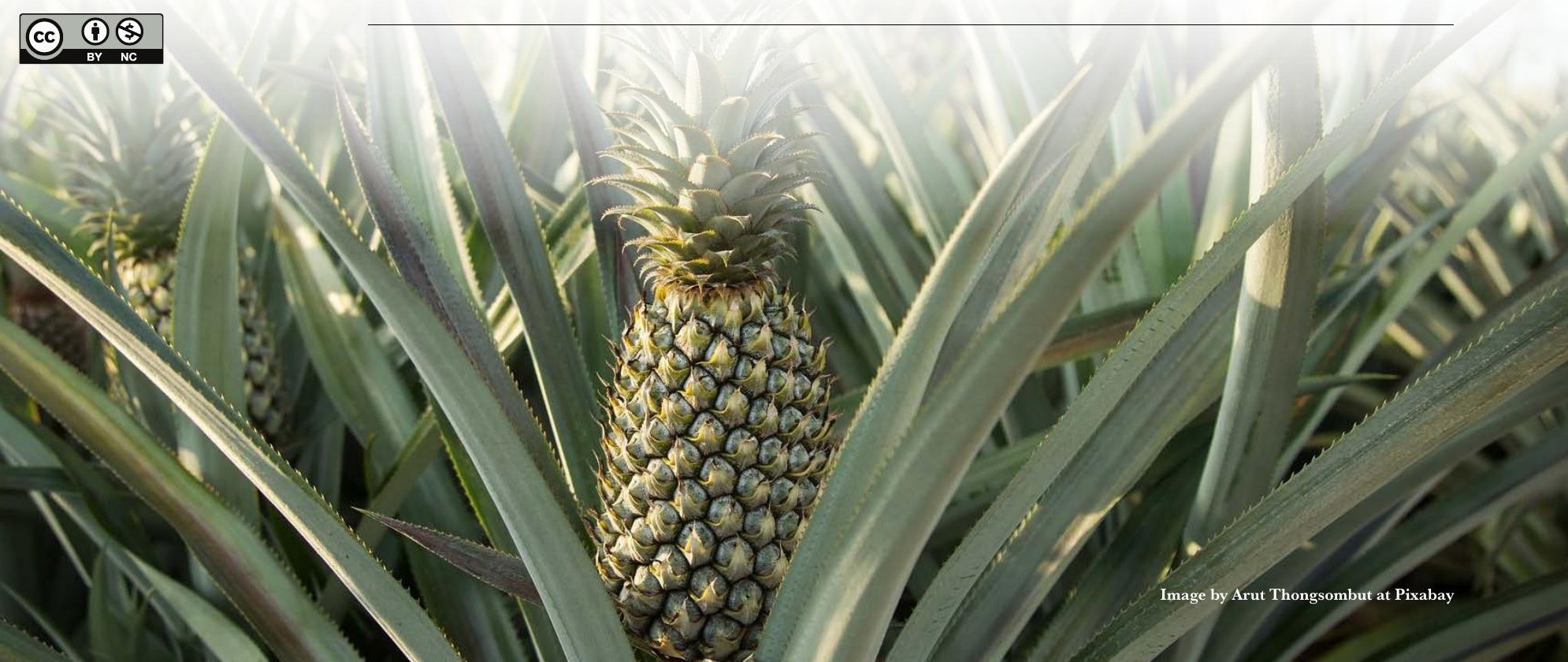




\section{INTRODUCTION}

Pineapple is a source of sugars, organic acids, and some essential minerals for human nutrition (Paull and Chen, 2003); it is also an antioxidant-rich fruit that promotes health; these natural antioxidants include ascorbic acid and phenolic compounds (Hossain et al., 2011; Lu et al., 2014). Ascorbic acid has a high bioavailability and can inhibit the development of cardiovascular diseases and certain types of cancer, protecting the membranes and the lipoproteins from oxidative damage (Gardner et al., 2000; Ferreira et al., 2016). The phenolic compounds are responsible for the sourness, astringency, taste, color, and oxidative stability of fruits and vegetables; these compounds protect health, removing free radicals and inhibiting hydrolytic and oxidating enzymes, and they also have antiinflammatory functions (Naczk and Shahidi, 2004). The Cabezona pineapple is produced and commercialized in La Chontalpa, Tabasco. However, there is no information about its chemical properties and the bioactive compounds content of its fruit.

\section{MATERIALS AND METHODS}

\section{Location}

The experiment was carried out in a field where Cayenne, MD2, and Cabezona pineapples have been grown for many years. This field is located in the Huimanguillo municipality, Tabasco, at $17^{\circ} 40^{\prime} \mathrm{N}$ and $93^{\circ} 38^{\prime} \mathrm{W}$, at 17 masl.

\section{Vegetable Material}

Basal shoots (also known as spikes or thorns) from pineapple vegetable material were used for this experiment; these basal shoots came from a Cabezona pineapple cultivar and weighted $370 \mathrm{~g}$.

\section{Treatments and Experimental Design}

The following NPK levels were evaluated: $\mathrm{N}$ (urea) (120, 160, 200, and $240 \mathrm{~kg} \mathrm{ha}^{-1}$ ); $\mathrm{P}$ (DAP) $\left(70,110,150\right.$, and $190 \mathrm{~kg} \mathrm{ha}^{-1}$ of $\left.\mathrm{P}_{2} \mathrm{O}_{5}\right)$; and $\mathrm{K}(\mathrm{KCl})(150,200,250$, and 300 $\mathrm{kg} \mathrm{ha}^{-1}$ of $\mathrm{K}_{2} \mathrm{O}$ ). Treatments were generated through the Plan Puebla 1 matrix (Turrent, 1985) and were evaluated in a random complete block design with four repetitions.

\section{Study Variables}

Fruits with optimal physiological ripeness that had undergone a fertilization treatment were used to determine the following chemical properties: $\mathrm{pH},{ }^{\circ}$ Brix, and titratable acidity. The following bioactive compounds were determined: ascorbic acid and total polyphenol and flavonoid contents. The $\mathrm{pH}$ was directly measured from the juice, using a PC18 Conductronic potentiometer. ${ }^{\circ}$ Brix were measured directly from the juice, as established in NMX-FF-015-1982, using an Atago ${ }^{\circledR}$ handheld refractometer, with a 0-33 ${ }^{\circ}$ Brix measurement range. Titratable acidity was determined following the methodology established in NMX-FF-011-1982; the results were expressed as citric acid percentage (\%). The ascorbic acid concentration was determined using a SIGMA-ALDRICH ${ }^{\circledR}$ ascorbic acid detection kit; the results were expressed as mg of ascorbic acid $100 \mathrm{~g}^{-1}$ of fresh fruit (FF). The total polyphenol content concentration was determined following the method 
described by De la Cruz-Ricardez et al. (2020) with some modifications. The galic acid was used as standard; the results were expressed as $\mathrm{mg} 100 \mathrm{~g}^{-1}$ of fresh fruit. The total flavonoid content concentration was determined following a modified version of the methodology described by Hossain et al. (2011), using quercetin as standard; the results were expressed as $\mathrm{mg} 100 \mathrm{~g}^{-1}$ of fresh fruit.

\section{Statistical Analysis}

In order to verify the assumption of normality and homogeneity of the variances, a RDBA ANOVA and a 0.05 Tukey test were carried out to analyze all the variables, using the Rstudio statistical kit, version 3.5.1 (Gentleman and Ihaka, 1993).

\section{RESULTS AND DISGUSSION}

\section{Ghemical Properties}

$p H$

There was no statistical difference between treatments; in a 1/4 color (NMX-FF-028SCFI-2008), the Cabezona pineapple had a mean $\mathrm{pH}$ of 3.4 (Table 1). This $\mathrm{pH}$ value is similar to the results reported by Lu et al. (2014) for the Smooth Cayenne \#1 (3.58), Smooth Cayenne \#2 (3.86), Comte de Paris (3.93), and Ripley (3.91) cultivars. This pH value is also similar to the findings of Da Silva et al. (2014): Victoria (3.6), Perola (3.8), Gold (3.8), and EG-93 (3.8) pineapples. In their study, Morales et al. (2001) reported 3.8-4.10 pH values for the Indian pineapple.

Figure 1 shows the graphic response to NPK fertilization; in the N-110-200 curve the highest $\mathrm{pH}$ value was obtained with $200 \mathrm{~kg} \mathrm{ha}^{-1}$ of $\mathrm{N}$, while in the $\mathrm{N}-150-250$ curve the highest $\mathrm{pH}$ values were obtained with 160 and $240 \mathrm{~kg} \mathrm{ha}^{-1}$. Meanwhile, the highest $\mathrm{pH}$ values were obtained with 70,110, and $190 \mathrm{~kg} \mathrm{ha}^{-1}$ of P. Finally, the highest values for the $\mathrm{K}$ doses were obtained with $200 \mathrm{~kg} \mathrm{ha}^{-1}$. The T6(200-110-250) has an acceptable pH and it was also associated with a higher fresh fruit yield (Pérez-Romero et al., 2020).

\section{${ }^{\circ}$ Brix}

There were no statistical differences on the NPK fertilization regarding ${ }^{\circ}$ Brix; the mean value was $7.3^{\circ}$ Brix (Table 1). According to the NMX-FF-028-SCFI-2008, in order to be commercialized, MD2, Cayenne Lisa, and Champala pineapple cultivars must have at
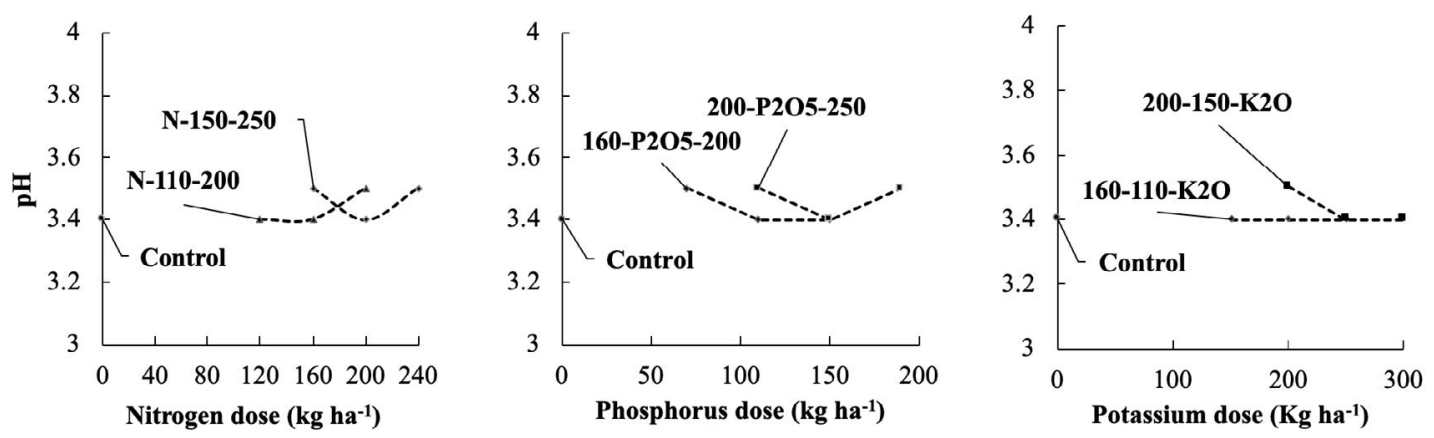

Figure 1. Response of the Cabezona pineapple juice's pH to NPK fertilization. 
Table 1. Chemical properties (pH, ${ }^{\circ}$ Brix, and citric acid \%) resulting from the different fertilization treatments carried out in Cabezona pineapples.

\begin{tabular}{|c|c|c|c|}
\hline $\begin{array}{l}\text { Fertilization treatments } \\
\left(\mathrm{kg} \mathrm{ha}^{-1} \text { de } \mathrm{N}, \mathrm{P}_{2} \mathrm{O}_{5}, \mathrm{~K}_{2} \mathrm{O}\right)\end{array}$ & pH & ${ }^{\circ}$ Brix & Citric acid, \% \\
\hline $\mathrm{Tl}_{(160-110-200)}$ & $3.4 \mathrm{a}$ & $7.1 \mathrm{a}$ & $0.77 \mathrm{a}$ \\
\hline $\mathrm{T} 2_{(160-110-250)}$ & $3.4 \mathrm{a}$ & $7.4 \mathrm{a}$ & $0.76 \mathrm{a}$ \\
\hline $\mathrm{T} 3_{(160-150-200)}$ & $3.4 \mathrm{a}$ & $7.2 \mathrm{a}$ & $0.78 \mathrm{a}$ \\
\hline $\mathrm{T} 4_{(160-150-250)}$ & $3.5 \mathrm{a}$ & $7.0 \mathrm{a}$ & $0.71 \mathrm{a}$ \\
\hline $\mathrm{T} 5_{(200-110-200)}$ & $3.5 \mathrm{a}$ & $6.9 \mathrm{a}$ & $0.69 \mathrm{a}$ \\
\hline $\mathrm{T} 6_{(200-110-250)}$ & $3.5 \mathrm{a}$ & $7.7 \mathrm{a}$ & $0.71 \mathrm{a}$ \\
\hline $\mathrm{T}_{(200-150-200)}$ & $3.5 \mathrm{a}$ & $7.1 \mathrm{a}$ & $0.67 \mathrm{a}$ \\
\hline $\mathrm{T}_{(200-150-250)}$ & $3.4 \mathrm{a}$ & $7.9 \mathrm{a}$ & $0.76 \mathrm{a}$ \\
\hline $\mathrm{T9}_{(120-110-200)}$ & $3.4 \mathrm{a}$ & $7.4 \mathrm{a}$ & $0.74 a$ \\
\hline $\mathrm{T} 0_{(240-150-250)}$ & $3.5 \mathrm{a}$ & $7.3 \mathrm{a}$ & $0.75 \mathrm{a}$ \\
\hline $\mathrm{T} 11_{(160-70-200)}$ & $3.5 \mathrm{a}$ & $7.7 \mathrm{a}$ & $0.60 \mathrm{a}$ \\
\hline $\mathrm{T} 12_{(200-190-250)}$ & $3.5 \mathrm{a}$ & $5.8 \mathrm{a}$ & $0.68 \mathrm{a}$ \\
\hline $\mathrm{T} 3_{(160-110-150)}$ & $3.4 \mathrm{a}$ & $7.4 \mathrm{a}$ & $0.76 a$ \\
\hline $\mathrm{T} 4_{(200-150-300)}$ & $3.4 \mathrm{a}$ & $7.8 \mathrm{a}$ & $0.79 \mathrm{a}$ \\
\hline $\mathrm{T} 15_{(00-00-00)}$ & $3.4 \mathrm{a}$ & $6.0 \mathrm{a}$ & $0.61 \mathrm{a}$ \\
\hline Media & 3.4 & 7.3 & 0.71 \\
\hline G.V. (\%) & 0.02 & 0.08 & 0.08 \\
\hline Prob. De F. & $0.28^{\text {ns }}$ & $0.18^{\mathrm{ns}}$ & $0.20^{\mathrm{ns}}$ \\
\hline DMS & 0.24 & 2.54 & 0.27 \\
\hline
\end{tabular}

*Means with the same letters are not statistically different (Tukey, 0.05). C.V. $=$ variance coefficient; DMS = significative minimum difference; Prob. De F.=Fisher probability.

least 12,11 , and $11^{\circ}$ Brix respectively, regardless of their ripening degree. This norm does not take into account the Cabezona pineapple, probably because it is a cultivar of regional importance. Additionally, the mean value ( $\left.{ }^{\circ} \mathrm{Brix}\right)$ of Cabezona pineapples is far below the results reported by other authors, such as Ulloa et al. (2015) for Comte de Paris (16.94), Smooth Cayenne \#2 (14.95), and Queensland (17.80) cultivars or Da Silva et al. (2014) for Victoria (16) and Perola (13.10) cultivars. A possible cause of these low ${ }^{\circ}$ Brix values in the Cabezona pineapple could be the ripening degree and the harvest season, because those values increase as the fruit ripens (Rosas et al., 2011) and they decrease during the season of North's winds (Uriza et al., 2018).

Figure 2 shows, on the one hand, the response of ${ }^{\circ}$ Brix to the dose of $\mathrm{N}$ : when low amounts of fertilization (N-110-200 curve) are used, the ${ }^{\circ}$ Brix decrease as the doses of $\mathrm{N}$ increase. On the other hand, when high fertilization doses (N-150-250 curve) are used, ${ }^{\circ}$ Brix increase, reaching their maximum level at $200 \mathrm{~kg} \mathrm{ha}^{-1}$ of $\mathrm{N}$ and then they tend to decrease. Figure 2 also shows the ${ }^{\circ}$ Brix response to the application of $\mathrm{P}$, where both curves (200- $\mathrm{P}_{2} \mathrm{O}_{5}-250$ and $\left.160-\mathrm{P}_{2} \mathrm{O}_{5}-200\right)$ indicate that ${ }^{\circ} \mathrm{Brix}$ decrease as the doses of $\mathrm{P}$ increase. Regarding $\mathrm{K}$, there was little difference in ${ }^{\circ}$ Brix in the $160-110-\mathrm{K}_{2} \mathrm{O}$ curve when its dose increased. However, when high doses of fertilization $\left(200-150-\mathrm{K}_{2} \mathrm{O}\right)$ were applied, ${ }^{\circ}$ Brix increased as the doses of $\mathrm{K}$ increased. This behavior has already been reported by $\mathrm{Py} e t$ 

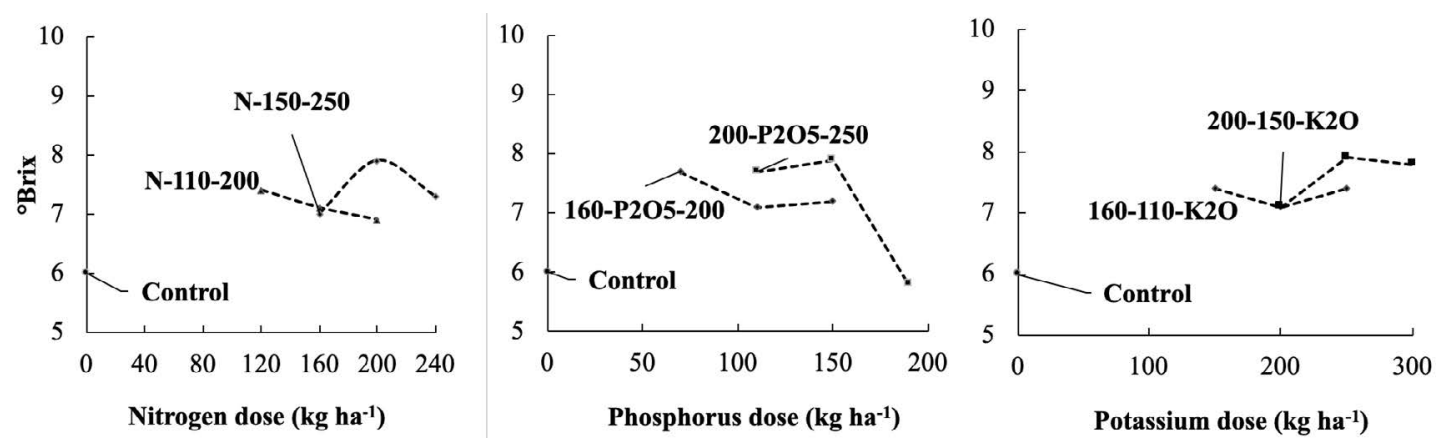

Figure 2. Response of the pineapple cultivar's ${ }^{\circ}$ Brix to NPK fertilization.

al. (1987), Rebolledo et al. (2011), and Uriza et al. (2018), who point out that K is directly responsible for the quality of the pineapple fruit.

\section{Citric Acid Percentage}

There was no statistical difference between NPK fertilization treatments; the citric acid mean value was $0.73 \%$ (Table 1 ). This value was similar to the results reported by Lu et al. (2014) for the Comte de Paris pineapple (0.73\%) and the Giant Kew pineapple (0.69\%). Additionally, this value falls within the range reported by Rosas et al. (2011) for the Esmeralda pineapple (0.4-1.2\%). However, this value could increase just like in the case of the Esmeralda pineapple, where the citric acid concentration increases as it ripens (Rosas et al., 2011), contrary to what happens with other tropical fruits such as mango, passion fruit, and papaya (Torres et al., 2013). This study corroborated that citric acid concentration increases during the rainy season and with the use of KCI as source of the $\mathrm{K}_{2} \mathrm{O}$; fertilization treatments exceed the unfertilized control in one unit (Rebolledo et al., 2011; Uriza et al., 2018).

Citric acid concentration did not show a clear response to the application of high or low doses of $\mathrm{N}$ (Figure 3); the highest concentrations in the N-110-200 and N-150-250 curves were obtained with $160 \mathrm{~kg} \mathrm{ha}^{-1}$ of $\mathrm{N}$ and 200 and $250 \mathrm{~kg} \mathrm{ha}^{-1}$ of $\mathrm{N}$, respectively. Figure 3 shows that citric acid concentration has a positive response to the increase of $\mathrm{P}_{2} \mathrm{O}_{5}$ doses; in both curves $\left(160-\mathrm{P}_{2} \mathrm{O}_{5}-200\right.$ and 200- $\left.\mathrm{P}_{2} \mathrm{O}_{5}-250\right)$, the highest concentration was obtained with $150 \mathrm{~kg} \mathrm{ha}{ }^{-1}$ of $\mathrm{P}_{2} \mathrm{O}_{5}$; concentrations tend to decrease after this dose. Additionally, high doses of $\mathrm{K}\left(200-150-\mathrm{K}_{2} \mathrm{O}\right.$ curve) can affect the citric acid concentration; concentration increased as the doses changed from 200 to $300 \mathrm{~kg} \mathrm{ha}^{-1}$ (Figure 3).

\section{Bioactive Compounds}

\section{Ascorbic Acid Concentration}

Highly significant differences were observed in the concentration of ascorbic acid in the NPK fertilization treatments (Table 2). The Tukey Test establishes five groups: the T13 and T15 treatments obtained the lowest concentration, while the T3, T6, T8, and T10 treatments obtained the highest concentrations. These results match those reported by Samson (1991), who found out that the ascorbic acid of pineapples varies from 8 to 30 mg $100 \mathrm{~g}^{-1} \mathrm{FF}$. Several authors have observed wider intervals (5.08-62.11 mg $100 \mathrm{~g}^{-1} \mathrm{FF}$ ) 

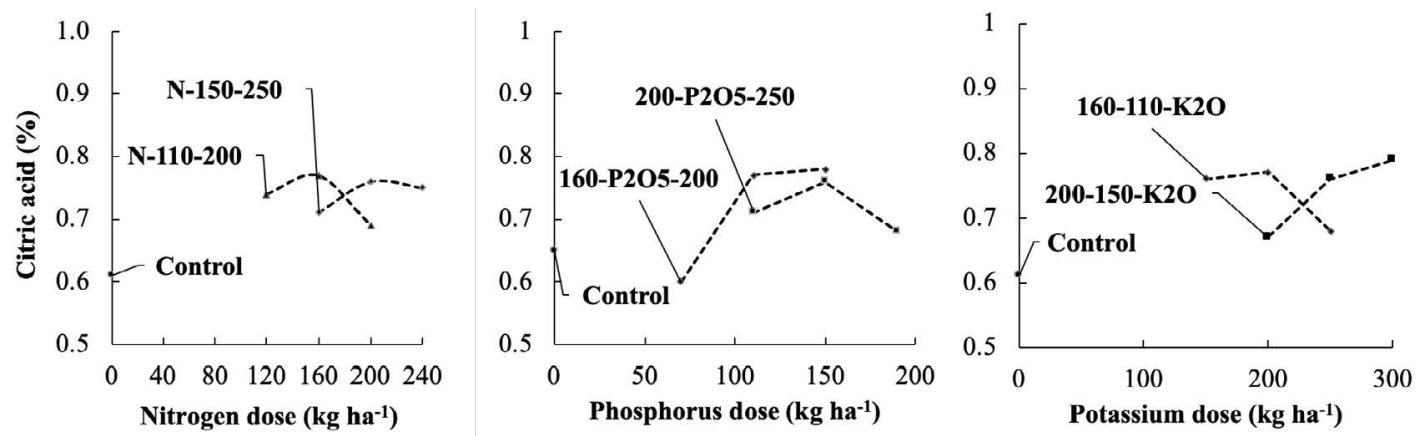

Figure 3. Response of the Cabezona pineapple juice's citric acid percentage to NPK fertilization.

Table 2. Bioactive compounds - ascorbic acid concentration in the different fertilization treatments of Cabezona pineapple.

\begin{tabular}{|c|c|c|c|}
\hline \multirow{2}{*}{$\begin{array}{l}\text { Fertilization treatments } \\
\left(\mathrm{kg} \mathrm{ha}^{-1} \text { de } \mathrm{N}, \mathrm{P}_{2} \mathrm{O}_{5}, \mathrm{~K}_{2} \mathrm{O}\right)\end{array}$} & Ascorbic acid & Total polyphenols & Total flavonoids \\
\hline & \multicolumn{3}{|c|}{ (mg $100 \mathrm{~g}^{-1}$ of fresh fruit) } \\
\hline $\mathrm{Tl}_{(160-110-200)}$ & $14.6 \mathrm{abc}$ & $41.4 \mathrm{a}$ & $1.8 \mathrm{a}$ \\
\hline $\mathrm{T} 2_{(160-110-250)}$ & $14.9 \mathrm{abc}$ & $46.3 \mathrm{a}$ & $1.5 \mathrm{a}$ \\
\hline $\mathrm{T} 3_{(160-150-200)}$ & $19.4 \mathrm{a}$ & $43.9 \mathrm{a}$ & $1.5 \mathrm{a}$ \\
\hline $\mathrm{T} 4_{(160-150-250)}$ & $14.6 \mathrm{abc}$ & $35.5 \mathrm{a}$ & $1.4 \mathrm{a}$ \\
\hline $\mathrm{T} 5_{(200-110-200)}$ & $11.8 \mathrm{abc}$ & $49.3 \mathrm{a}$ & $1.6 \mathrm{a}$ \\
\hline $\mathrm{T} 6_{(200-110-250)}$ & $19.4 \mathrm{ab}$ & $40.5 \mathrm{a}$ & $1.4 \mathrm{a}$ \\
\hline $\mathrm{T} 7_{(200-150-200)}$ & $11.3 \mathrm{abc}$ & $35.7 \mathrm{a}$ & $1.2 \mathrm{a}$ \\
\hline $\mathrm{T}_{(200-150-250)}$ & $16.0 \mathrm{ab}$ & $43.8 \mathrm{a}$ & $1.6 \mathrm{a}$ \\
\hline $\mathrm{T} 9_{(120-110-200)}$ & $14.7 \mathrm{abc}$ & $41.1 \mathrm{a}$ & $1.7 \mathrm{a}$ \\
\hline $\mathrm{T} 0_{(240-150-250)}$ & $15.1 \mathrm{ab}$ & $36.2 \mathrm{a}$ & $1.6 \mathrm{a}$ \\
\hline $\mathrm{T} 11_{(160-70-200)}$ & $13.4 \mathrm{abc}$ & $35.7 \mathrm{a}$ & $1.9 \mathrm{a}$ \\
\hline $\mathrm{T} 12_{(200-190-250)}$ & $11.3 \mathrm{abc}$ & $42.2 \mathrm{a}$ & $1.6 \mathrm{a}$ \\
\hline $\mathrm{T} 13_{(160-110-150)}$ & $6.2 \mathrm{c}$ & $43.2 \mathrm{a}$ & $1.9 \mathrm{a}$ \\
\hline $\mathrm{T} 4_{(200-150-300)}$ & $11.8 \mathrm{abc}$ & $42.7 \mathrm{a}$ & $1.7 \mathrm{a}$ \\
\hline $\mathrm{T} 15_{(0-0-0)}$ & $10.5 b c$ & $42.3 \mathrm{a}$ & 1.5 \\
\hline Media & 13.67 & 41.34 & 1.6 \\
\hline G.V. & 0.25 & 0.10 & 0.11 \\
\hline Prob. De F. & $0.001^{* *}$ & $0.30^{\mathrm{ns}}$ & $0.30^{\mathrm{ns}}$ \\
\hline DMS & 8.83 & 14.28 & 0.82 \\
\hline
\end{tabular}

*Means with the same letters are not statistically different (Tukey, 0.05). C.V.=variance coefficient; DMS = significative mean difference; Prob. De F. =Fisher probability.

for various pineapple cultivars, including: Ferreira et al. (2016), who reported 35.88-

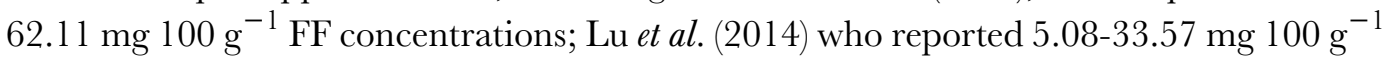
FF concentrations; and Da Silva et al. (2014), who reported 7.03-25.48 mg $100 \mathrm{~g}^{-1} \mathrm{FF}$ concentrations. We must mention that Morales et al. (2001) and Rosas et al. (2011) reported that ascorbic acid concentration increases in the Esmeralda and Indian pineapples as their fruit ripens. This effect could provide a possible explanation for the lack of much similarity in the concentrations reported by the authors. 
Ascorbic acid concentration does not show a clear response when the $\mathrm{N}$ doses increases (N-150-250 curve), although the highest concentration was obtained with 250 $\mathrm{kg} \mathrm{ha}{ }^{-1}$ of $\mathrm{N}$ per hectare (Figure 4); however, as the doses of $\mathrm{N}$ increase, the ascorbic acid concentration shows a clear decrease in the N-100-200 curve. With low fertilization doses (160- $\mathrm{P}_{2} \mathrm{O}_{5}-200$ curve), the ascorbic acid concentration increases as the dose of $\mathrm{P}$ increases, reaching a maximum concentration of $\mathrm{P}$ at $150 \mathrm{~kg} \mathrm{ha}^{-1}$. The opposite result is obtained with high fertilization doses $\left(200-\mathrm{P}_{2} \mathrm{O}_{5}-250\right)$ : the ascorbic acid concentration decreases as the doses of $\mathrm{P}$ increase, reaching a minimum concentration of $190 \mathrm{~kg} \mathrm{ha}^{-1}$. As a result of the positive interaction, the 200-150- $\mathrm{K}_{2} \mathrm{O}$ curve, with $250 \mathrm{~kg} \mathrm{ha}^{-1}$ of $\mathrm{K}_{2} \mathrm{O}$, has the highest ascorbic acid concentration (Figure 4); meanwhile, the ascorbic acid concentration increases in the $160-110-\mathrm{K}_{2} \mathrm{O}$ curve, with 200 and $250 \mathrm{~kg} \mathrm{ha}-1$ doses of $\mathrm{K}_{2} \mathrm{O}$, although this increase is lower than the one reported for the 200-150$\mathrm{K}_{2} \mathrm{O}$ curve.

\section{Total polyphenols content}

There were no significative differences between fertilization treatments (Table 2). Total

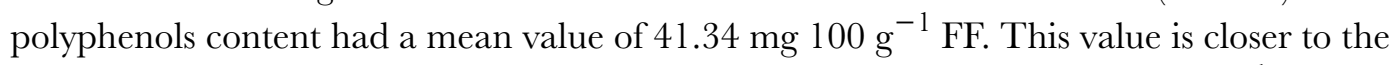
results reported by $\mathrm{Lu}$ et al. (2014) for various cultivars (37.48-77.55 $\mathrm{mg} 100 \mathrm{~g}^{-1} \mathrm{FF}$ ), by Rosas et al. (2011) for Esmeralda pineapples (44.78 mg $100 \mathrm{~g}^{-1} \mathrm{FF}$ ), and by Ferreira $e t$ al. (2016), likewise for several cultivars (71.08-126.95 mg $\left.100 \mathrm{~g}^{-1} \mathrm{FF}\right)$. These differences can be the result of the type of cultivar and the ripening degree of the pineapple fruits. Polyphenols content — as well as ascorbic acid content - increases in Esmeralda pineapples as the fruit ripens.

The maximum polyphenols content was found at $200 \mathrm{~kg} \mathrm{ha}^{-1}$ of $\mathrm{N}$ for high and low fertilization doses (N-110-200 and N-150-250 curve); however, polyphenols content shows a drastic decrease with a 200 to $240 \mathrm{~kg} \mathrm{ha}^{-1}$ of $\mathrm{N}$ increase and high fertilization doses (Figure 5). Increasing doses of $\mathrm{P}$ provide a better response: polyphenols content increases as the doses increase, reaching a maximum content with $150 \mathrm{ha}^{-1}$ of $\mathrm{P}$; however, content tends to decrease with higher doses (Figure 5). Meanwhile, potassium had a poor response: the highest polyphenols content was obtained with $250 \mathrm{~kg}^{-1}$ of $\mathrm{K}_{2} \mathrm{O}$ for both curves $\left(160-110-\mathrm{K}_{2} \mathrm{O}\right.$ and $\left.200-150-\mathrm{K}_{2} \mathrm{O}\right)$.
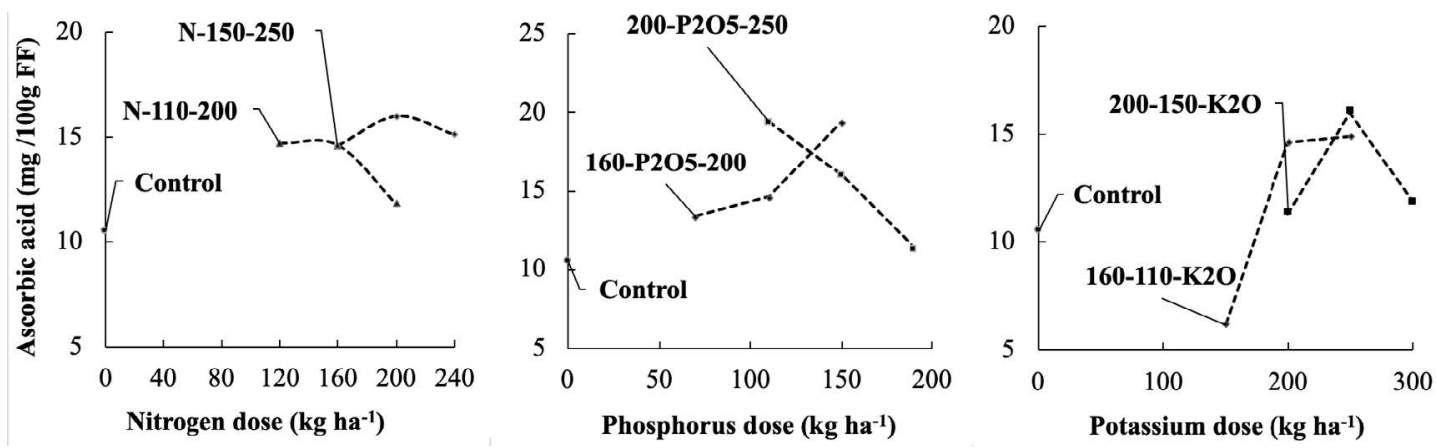

Figure 4. Response of the Cabezona pineapple juice's ascorbic acid percentage to NPK fertilization. 

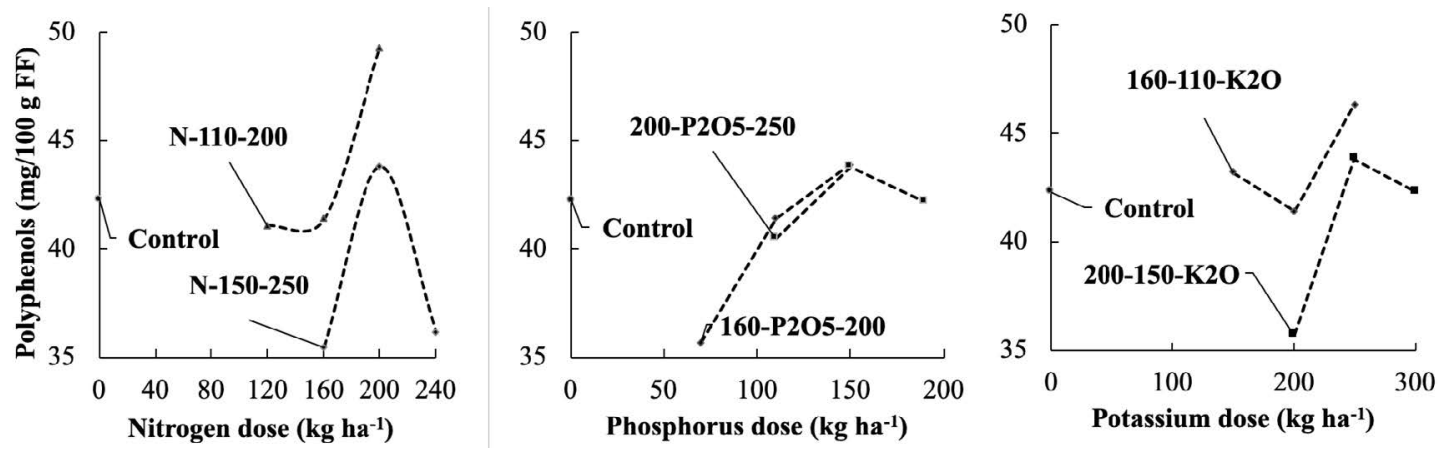

Figure 5. Response of the total polyphenols content in Cabezona pineapples to NPK fertilization.

\section{Total flavonoids content}

There were no statistical differences between fertilization treatments regarding the content of total flavonoids content (Table 2). The mean concentration was $1.6 \mathrm{mg} 100 \mathrm{~g}^{-1}$ FF.

The flavonoids content in Cabezona pineapples were different from the results obtained

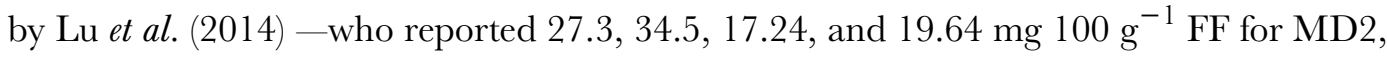
Comte de Paris, Fresh Premium, and Pearl, respectively - and by Hossain et al. (2011) -who reported $51.1 \mathrm{mg} 100 \mathrm{~g}^{-1} \mathrm{FF}$ for tropical pineapples. These differences are likely the result of the color of the flesh of the Cabezona pineapple, which is paler than the flesh coloration percentage of the MD2 pineapple (63-87\%); flavonoids are responsible for the color and taste of fruits and vegetables.

The flesh of the Cabezona pineapple could also have a lower browning tendency than other cultivars; therefore, its capacity to synthesize the flavonoids that are involved in the prevention of oxidation would be low and this process allows the protection of existing vitamins and enzymes. Another potential cause could be the low levels of glucose - the precursor molecule of the synthesis of flavonoids - in the flesh (Martínez et al., 2002; Mandalar et al., 2006).

The effect of $\mathrm{N}$ doses on flavonoids content is not clear: the contents obtained with low fertilization doses (N-110-200 curve) are higher than the contents obtained with high fertilization doses (N-150-250 curve) (Figure 6). The flavonoids content response to
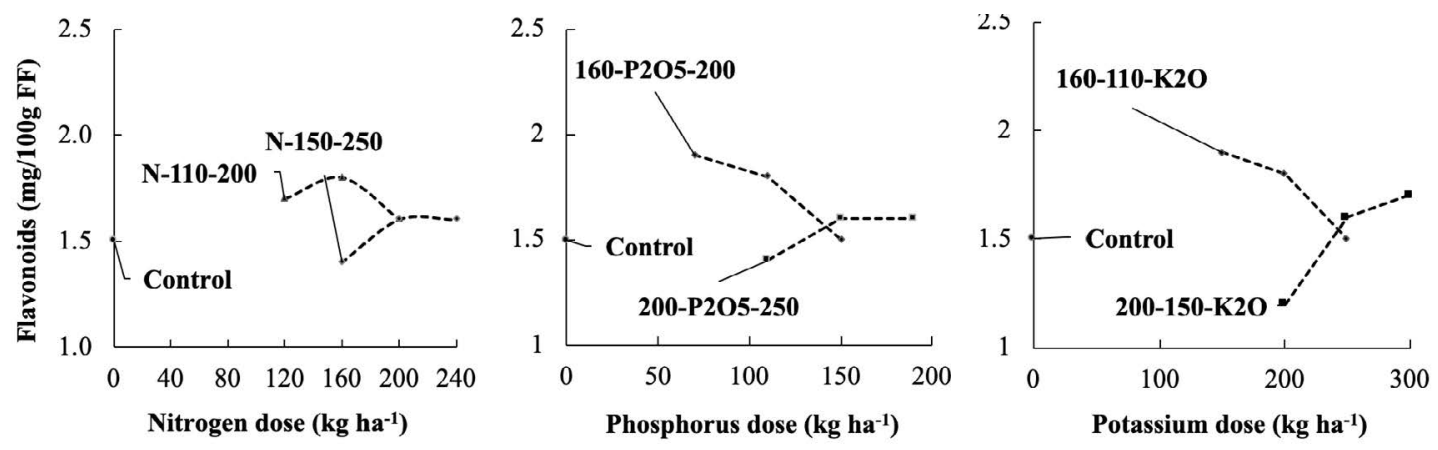

Figure 6. Response of the flavonoids content in Cabezona pineapples to NPK fertilization. 
increasing $\mathrm{P}$ and $\mathrm{K}$ doses are similar. Content tends to decrease with low fertilization doses (160- $\mathrm{P}_{2} \mathrm{O}_{5}-200$ and 160-110- $\mathrm{K}_{2} \mathrm{O}$ curve), while it increases with high doses of the same nutrients (200- $\mathrm{P}_{2} \mathrm{O}_{5}-250$ and $200-150-\mathrm{K}_{2} \mathrm{O}$ curve), reaching maximum $\mathrm{P}$ and $\mathrm{K}$ levels of 150 and $200 \mathrm{~kg} \mathrm{ha}^{-1}$ and $300 \mathrm{~kg} \mathrm{ha}^{-1}$, respectively.

\section{CONGLUSIONS}

NPK fertilization did not have a significative effect on $\mathrm{pH}$ and ${ }^{\circ} \mathrm{Brix}$. The application of $\mathrm{N}$ and $\mathrm{K}$ does not affect the citric acid percentage and the total polyphenols content; however, they increase along with the $\mathrm{P}_{2} \mathrm{O}_{5}$ doses and they reach a maximum concentration at 150 $\mathrm{kg} \mathrm{ha}^{-1}$. NPK fertilization did not affect the ascorbic acid and flavonoids concentration.

\section{REFERENCES}

Da Silva, B. S., De Jesus, F. S., Cesar, D. S. P., Goncalves, O. J., \& Santos, C. L. C. (2014). Avaliação da qualidade de frutos de quatro genótipos de abacaxi para consumo in natura. Rev. Bras. Frutic, 36(2): 503-508. Doi:10.1590/0100-2945-100/13.

De la Cruz-Ricardez, D., Ortiz-García, C:F., Lagunes-Espinoza, L.C., Torres-de la Cruz, M., \& HernándezNataren, E. (2020). Compuestos fenólicos, carotenoides y capsaicinoides en frutos de Capsicum spp. de Tabasco, México. Agrociencia, 54: 505-519.

Ferreira, E. A., Siqueira, H. E., Villasboas, E. V., Hermes, V. S., \& Rios, A. D. O. (2016). Bioactive compounds and antioxidant activity of pineapple fruit of different cultivars. Rev. Bras. Frutic., Jaboticabal - SP, 38 (3): e-146. Doi:10.1590/0100-29452016146

Gardner, P. T., White, T. A. C., McPhail, D. B., \& Duthie, G. G. (2000). The relative contribution of vitamin C, carotenoids and phenolics to the antioxidant potential of fruit juices. Food Chemistry, 68: 471-474. Doi: 10.1016/S0308-8146(99)00225-3

Gentleman, R., \& Ihaka, R. (1993). R Studio (Version 3.5.1.). Departamento de Estadística de la Universidad de Auckland.

Hossain, A. M., \& Rahman, M. S. M. (2011). Total phenolics, flavonoids and antioxidant activity of tropical fruit pineapple. Food Research International, 44: 672-676. Doi:10.1016/j.foodres.2010.11.036

Lu, X. H., Sun, D. Q., Wu, Q. S., Liu. S. H., \& Sun, G. M. (2014). Physico-Chemical Properties, Antioxidant Activity and Mineral Contents of Pineapple Genotypes Grown in China. Rev. Molecules, 19: 8518-8532. Doi: 10.3390/molecules 19068518

Martínez, F. S., González, G. J., Culebras, J. M., \& Tuñon, M. J. (2002). Los flavonoides: propiedades y acciones antioxidantes. Rev. Nutrición Hospitalaria, 17: 271-278.

Mandalar, I. G., Bennett, R. N., Bisignano, G., Saija, A., Dugo, G., Lo Curto, B. R., Faulds, B. C., \& Waldron, W. K. (2006). Characterization of flavonoids and pectins from bergamot (Citrus bergamia Risso) peel, a major byproduct of essential oil extraction. Journal of Agricultural and Food Chemistry, 54:197-203. Doi: $10.1021 / \mathrm{jf051847n}$

Morales, M., Hernández, M. S., Cabezas, M. Barrera, J., \& Martínez, O. (2001). Caracterización de la maduración del fruto de piña nativa (Ananas comosus L. Merrill) GV. India. Agronomía Colombiana, 18 (1-2): 7-13.

Naczk, M., \& Shahidi, F. (2004). Extractions and analysis of phenolics in food. Journal of Chromatography A, Amsterdam, 1054(1/2). 95-111. Doi: 10.3390/molecules 18022328.

NMX-FF-028-SCFI-2008. (Productos alimenticios no industrializados para consumo humano-fruta frescapiña). (n.d.). 9 p. Recuperada de http://www.economianmx.gob.mx/normasmx/-index-.nmx.

NMX-FF-015-1982. Productos alimenticios no industrializados, para uso humano. fruta fresca. determinación de sólidos solubles totales. Normas mexicanas. dirección general de normas. 19 p. Recuperada de https://www.colpo-s.mx/bancodenormas-/nmexicanas/NMX-FF-015-1982.PDF.

NMX-FF-01 1-1982. Productos alimenticios no industrializados, para uso humano. fruta fresca. determinación de acidez titulable. método de titulación. Normas mexicanas. dirección general de normas. 4 p. Recuperada de http-s://www.colpos.mx/bancodenormas/nmexicanas/NMX-FF-01 1-1982.PDF.

Paull, R. E., \& Chen, C. C. (2003). Postharvest physiology, handling and storage of pineapple. In The Pineapple: Botany, Production and Uses; Bartholomew, D.P., Paull, R.E., Rohrbach, K.G., Eds.; CABI Publishing: New York, NY, USA. Pp. 253-279. Doi: 10.1079/9780851995038.0000. 
Pérez-Romero, J., Salgado-García, S., Córdova-Sánchez, S., Lagunes-Espinoza, L.C., Ortiz-García, C.F. (2020). Evaluation of growth parameters in "cabezona" pineapple (Ananas comosus (L.) Merr.) in response to NPK fertilization. Agroproductividad, 13(8): 3-9. Doi: 10.32854/agrop.vi.1797.

Py, G., Lacoeuilhe, J. J., \& Teisson, C. (1987). The pineapple: cultivation and uses. Paris: Maisonneuve \& Larose. 568 p.

Rebolledo, M., A., Uriza, D. E. Del Ángel, P. A. L., Rebolledo, L., \& Zetina, L. R. (2011). La piña y su cultivo en México: Cayena Lisa y MD2. México: Instituto Nacional de Investigaciones Forestales, Agrícolas y Pecuarias. Campo Experimental Papaloapan, Medellín de Bravo, Ver. (27): 20-120.

Rosas, D. G., González, A. G. A., Ayala, Z. J. F., Mendoza, W. A. M., \& Ruiz, C. S. (2011). Contenido de compuestos bioactivos y su contribución a la capacidad antioxidante durante la maduración de piña cv. "Esmeralda". Tesis de Maestría en Ciencias Alimentarias. Centro de Investigación en Alimentación y Desarrollo, A.C. Hermosillo, Sonora. Pp. 42-50.

Samson, J. (1991). Fruticultura tropical. Limusa-Noruega. México. 229-258.

Torres, R. E., Montes, J., Omar, P. A., \& Ricardo, D. A. (2013). Relación del Color y del Estado de Madurez con las Propiedades Fisicoquímicas de Frutas Tropicales. Tecnol., 24(3): 51-56. Doi: 10.4067/S071807642013000300007.

Turrent, A. (1985). El método grafico-estadístico para la interpretación económica de experimentos conducidos con la matriz Plan Puebla I. Colegio de Posgraduados Chapingo. 65 p.

Ulloa, L., Vinicio, S. M., \& Castro, J. (2015). Efecto del almacenamiento a diferentes temperaturas sobre el desarrollo de color externo y la calidad de frutos de piña cv. Dorada extra dulce. Agronomía Costarricense, 39(3): 9-20.

Uriza, D. E., Torres, A. A., Aguilar, A. J., Santoyo, V. H., Zetina, L. R., \& Rebolledo, A. A. (2018). La piña mexicana frente al reto de la innovación. Avances y retos en la gestión de la innovación. Colección Trópico Húmedo. Chapingo, Estado de México. México: UACh. 479 p. 